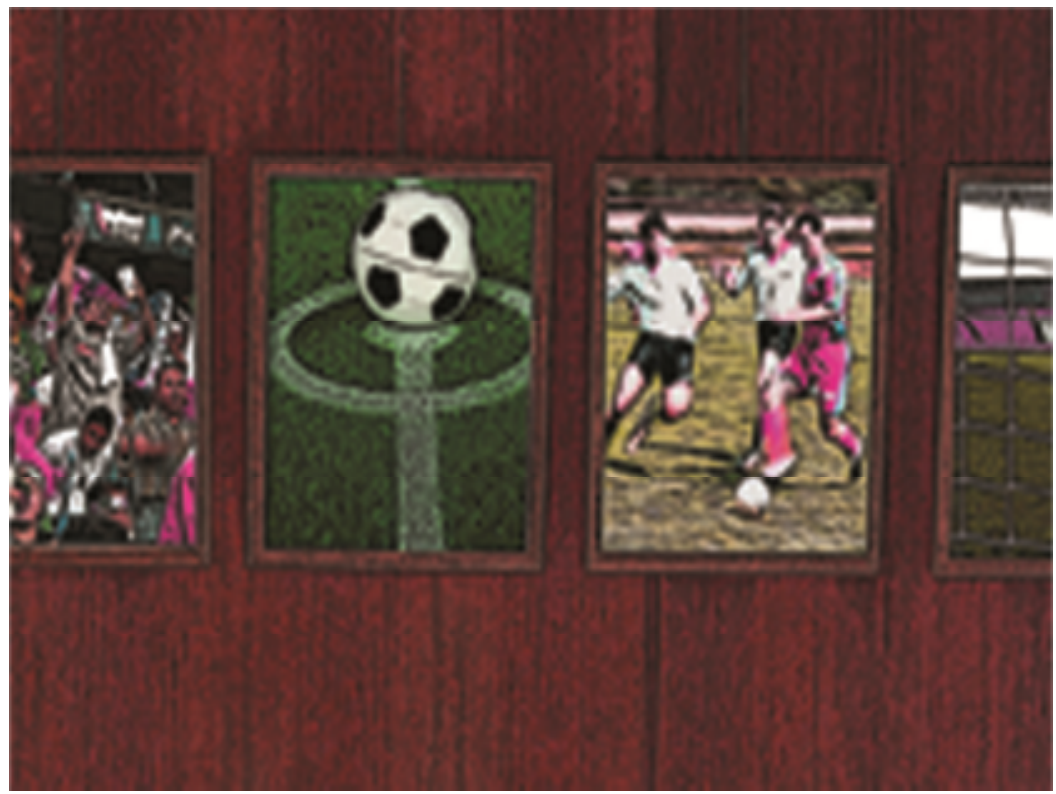

Felipe Mesquita

\title{
Museu do futebol, museu do torcedor
}

\section{Juliana Leal}

Juliana Leal é doutoranda em Literatura Comparada, FALE/UFMG. Mestre em Estudos Literários e professora de Língua Espanhola.

\section{Resumo}

O Museu do Futebol, recentemente inaugurado no Estádio Pacaembu, em São Paulo, Brasil, é a realização bem-sucedida do conceito de museu contemporâneo, a partir do qual o público visitante se vê estimulado a acessar seus arquivos pessoais para construir, junto com objetos, imagens, textos auditivos, visuais e textuais, bem como dispositivos de interatividade multimídia, reunidos no museu, uma narrativa própria sobre a história do futebol que o inclua também como agente participante e não só como mero espectador.

Palavras-chave: museu, memória, arquivos, corporeidade, interatividade. 
Beatriz Sarlo - professora e crítica de arte, literatura e cultura -, no artigo "A literatura na esfera pública", chama a atenção para uma extensão inimaginável, em alguns países, da arte na vida cotidiana. Ela aponta para o crescimento do mercado de objetos e práticas culturais das artes visuais, dos museus, das cidades e do turismo, revelando que uma exposição de arte bem-sucedida pode provocar tanto interesse quanto o final de um campeonato de futebol. É nessa perspectiva que o Museu do futebol(1) recentemente inaugurado no Estádio Pacaembu, em São Paulo, parece ter sido idealizado. Partindo da exploração produtiva do vasto viés cultural inerente a manifestações freqüentemente rotuladas como populares, esse museu encanta e ensina, ao mesmo tempo.

O termo "museu", aparentemente, nada tem a ver com "futebol", mas a idéia clássica de museu como mero lugar de exposição de objetos, reservado à contemplação burguesa, há algum tempo vem sendo rediscutida. O Museu do futebol não indexa, pura e simplesmente, fatos, objetos e narrativas mais relevantes da história do futebol no Brasil e de sua repercusão no contexto global. Pelo contrário, ele apresenta o esporte como uma forte manifestação da cultura brasileira, presente nos mais diversos contextos artísticos, histórico-culturais e políticos. Assim, - Museu do futebol consegue integrar, harmoniosamente, os mais diversos discursos e visitantes, aproximando o público a partir daquilo que lhe é mais familiar.

Andreas Huyssen - professor, editor e crítico literáriocultural - ressalta a importância das tradições musicais e visuais na cultura brasileira, enfatizando a improdutividade de se tomar a cultura da mídia como algo restrito ao âmbito popular em um país como o Brasil onde, segundo ele, "a cultura é moldada mais por tradições musicais e visuais do reino popular do que pelo que Angel Rama chamou de a cidade letrada"(2). O Museu do futebol aplica essa "receita" pictórico-visual com maestria e muita tecnologia, garantindo filas expressivas na entrada, no percurso (caso o visitante queira cobrar um pênalti num campo no qual o virtual e o real se mesclam) e - pasmem! - na saída do museu.

Esse espaço cultural, a meu ver, parece ser uma realização bem-sucedida de um conceito contemporâneo de museu que rechaça a idéia positivista de arquivo enquanto "lugar fixo e corpo estável de registros históricos", enquanto "lugar de simples localização e ordenação de uma certeza" e que compreende a memória enquanto biografia(3), bem como a idéia de museu "enquanto loja de departamentos no qual a arte ou o objeto artístico se reduz ao estatuto de mercadoria"(4). O Museu do futebol é, ao contrário, a realização da memória enquanto cenografia(5), por permitir ao público (torcedor ou não) um reconhecimento enquanto sujeito construtor, enquanto ator (e 
não apenas espectador) da história do futebol brasileiro, bem como, de maneira direta ou indireta, dos diversos contextos culturais, políticos e históricos apresentados como cenários para a narração da história desse esporte. Por essa razão é que não deve ser gratuita a imagem em 3D do jogador Ronaldinho lançando, do telão, a bola para o visitante e sua automática reação em recebê-la.

Nesse museu, as possibilidades interpretativas para a seleção de fotografias, músicas, gravações radiofônicas, depoimentos de personalidades políticas e artísticas e fatos históricos se abrem para uma interação fluida com o imaginário social, cultural e histórico do espectador contemporâneo. Os significados fluem entre memórias e arquivos (os do museu e os dos visitantes) viabilizando infinitas possibilidades de conexões interpretativas para o arsenal de referências culturais neles citados. A etiqueta "torcedor", enquanto sujeito exterior aos arquivos ali reunidos, é redimensionalizada todo o tempo, ganhando um maior impacto na interação com um espaço específico do museu no qual imagens em cores de variadas torcidas organizadas são projetadas de forma sincrônica e palimpséstica entre as vigas, o cinza do cimento e o forte cheiro de umidade do local. Por considerar sua corporeidade também como arquivo, como um museu ambulante do futebol, os holofotes nos arquivos de imagens ali exibidas serão deslocados simultaneamente das imagens projetadas para o visitante que, num esforço descomunal, tentará reconhecer sua torcida - reconhecendo-se - em meio a um turbilhão de imagens sobrepostas.

Não deve ser à toa que o primeiro contato que o público tem com o museu parte de uma grande metáfora que define seu lugar em relação a todo o caudal de referenciais com os quais vai interagir a seguir: uma imagem em preto e branco - em tamanho real - de pelé, descendo as escadarias de um vestiário de um campo de futebol (escadarias que são, vale informar, do próprio edifício que abriga o museu). Vendo-o descer do topo dessa escadaria, somos inseridos, irremediavelmente, nesse lugar, tal como se ali também estivéssemos entrando. E certamente o faremos.

Entre bolas dentro de cubos de vidros, reproduzindo mimeticamente a lógica tradicional da exposição de conteúdos e objetos freqüentemente usada em museus tradicionais, e projeções multimídias de outras bolas em campos de futebol virtuais, na superfície de alguns espaços do museu, os visitantes interagem não somente com seleções de objetos, mas com o conhecimento difundido por esse esporte. Atuando como jogador e como torcedor, o visitante é levado a reconhecer-se como agente construtor não somente da história do futebol, mas da literatura, da política e da cultura brasileiras, em torno 
das quais essa arte pôde ganhar projeção no cenário internacional.

A visita a esse museu não permitirá, como ingenuamente acreditei, uma forma de interação com um objeto ou uma temática sob moldes decimonônicos, que valorizavam uma contemplação estéril e distanciada do receptor em relação ao objeto cultural. Trata-se de outra experiência, que coloca o visitante como parte integrante - e fundamental - da narrativa ali textualizada. Essa interação possibilita a realização de um diálogo capaz de iluminar conflitos morais, sociais, políticos e estéticos(6), porque 0 "museo personal" do visitante será posto, inevitavelmente, em funcionamento. No museu do futebol, tal como ocorre com a personagem-máquina Elena, do romance la ciudad ausente, do escritor argentino Ricardo Piglia, o espectador aprenderá à medida que se vê narrado, à medida que cada objeto, imagem, narrativa, projeção, música, foto etc., usados para compor o acervo do museu, colocar em funcionamento outras e infinitas imagens, narrativas, sons internalizados no museu de seu inconsciente porque, segundo Gisbourne, "todos nós somos arquivos, arquivos vivos e encarnados de conhecimento"(7).

\section{Resumen}

El Museo del Fútbol, recientemente inaugurado en el Estadio Pacaembu, São Paulo, Brasil, es la realización exitosa del concepto de museo contemporáneo, a partir del cual el público visitante se ve estimulado a acceder sus archivos personales para construir con los objetos, imágenes, textos auditivos, visuales y textuales, además de los dispositivos de interactividad multimedia, reunidos en el museo, una narrativa propia sobre la historia del fútbol que le incluya también como actor participante y no solamente mero comospectador.

Palabras-clave: museo, memoria, archivos, corporeidad, interactividad.

\section{Notas}

[1] MARQUES, 2002. p. 38.

[2] MARQUES, 2002. p. 30.

[3] GISBOURNE, $2008 . \mathrm{p} .5$.

[4] BENJAMIN, 2007. p. 458.

[5] GISBOURNE, $2008 . \mathrm{p} .5$.

[6] SARLO. In: MARQUES, VILELA. 2002 . p. 54.

[7] PIGLIA, 1992.

[8] GISBOURNE, $2008 . \mathrm{p} .6$. 


\section{Referências bibliográficas}

BENJAMIN, Walter. Passagens. Belo Horizonte, São Paulo: Editora UFMG, Imprensa Oficial do Estado de São Paulo, 2007.

GISBOURNE, Mark. Daniel Blaufuks: a polifonia da memória e a dissonância do arquivo. Disponível em: http://danielblaufuks.com/webmac/text/markport.html. Acesso em: 20/10/2008.

MARQUES, Reinaldo, VILELA, Lúcia Helena (orgs.).Valores: arte, mercado e política. Belo Horizonte: Editora UFMG/Abralic, 2002.

PIGLIA, Ricardo. Entrevista con Ricardo Piglia. In: PEREIRA, Maria Antonieta. Ricardo Piglia y sus precursores. Buenos Aires: Corregidor, 2001 .

La ciudaded ausent. Buenos Aires: Sudamericana, 1992. 